How to cite: Chelu, A. (2019) A Typology of Indices for Drought Assessment. 2019 "Air and Water - Components of the Environment" Conference Proceedings, Cluj-Napoca, Romania, p. 77-90, DOI: 10.24193/AWC2019 08.

\title{
A TYPOLOGY OF INDICES FOR DROUGHT ASSESSMENT
}

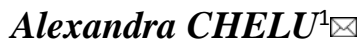 \\ DOI: $10.24193 / A W C 2019 \_08$
}

\begin{abstract}
Drought is one of the most disastrous and costly natural hazards determined by a deficit of precipitation in a particular area. It causes large economic losses and affects access to water in various parts of the planet. Water scarcity impacts natural ecosystems and human activities dependent on water resources, especially crop production. Monitoring drought is therefore crucial to the evaluation of its impacts and to address the issue in a timely manner, in order to develop and implement mitigation measures. Various methodologies have been advanced to quantify essential drought characteristics, such as time of onset and ending, duration and intensity. The objective of this paper is to review the existing indices used for drought identification and assessment and to propose an index typology. The study employs bibliographical research, synthesis and classification of indices by data source input and their aims. The results provide a brief overview of the drought indices based on measured or modelled data (meteorological, hydrologic or agricultural approaches), remote sensing data (hydrometeorological or ecological approaches) and multivariate or composite indices.
\end{abstract}

Keywords: drought index, remote sensing, precipitation, temperature

\section{INTRODUCTION}

Drought is one of the most devastating natural hazards that affects large extents of land and causes great economic losses. Drought is mostly determined by a deficit of water availability over a longer period of time, and it is intensified by meteorological constraints such as increasing temperatures or high winds (Mishra \& Singh, 2010). It affects both natural processes and human activities that are directly or indirectly dependent on water resources.

Some of the main impacts of droughts are the decrease in primary productivity (Ciais et al., 2005), decreasing streamflow, runoff, surface and ground water resources (Smakhtin, 2001), decreased electricity production (Van Vliet et al., 2016) and increased tree mortality by tree die-off and wildfires (Allen et al., 2010). Drought is likely to increase over Europe, especially in the south and western regions, and less so in the north (Spinoni et al., 2018), promoted by the continuing increasing trend in temperature (Hoegh-Guldberg et al., 2018)

\footnotetext{
${ }^{1}$ University of Bucharest, Faculty of Geography, Bd. Nicolae Bălcescu 1, 010041 Bucharest, e-mail: mariaalexandra.chelu@gmail.com
} 
The complex nature of drought events comes from the multiple definitions that characterize them, from the complicated relations between types of drought (Heim, 2002) and from the difficulty of identifying the onset and offset of drought (Wilhite, 2000). The fact that drought is extended over large regions and does not create structural damages contributes to the difficulty of assessing and quantifying impacts (Wilhite, 2000).

Drought is classified in four main types: meteorological, hydrological, agricultural or socio-economical droughts (Kallis, 2008). Mishra and Singh (2010) have also introduced the term groundwater drought as a distinct type; however, it could be considered as one aspect of hydrological droughts.

Several studies have also proposed the ecological drought type, focusing on the effects of drought on water quality or ecological characteristics of water bodies (Bachmair et al., 2016).

It is essential for planning authorities to identify temporal and spatial patterns of established droughts, to access aridity prognosis and to publicly communicate the results for a better mitigation plan and preparedness.

The quantification of drought is performed with the help of indices, which are used to calculate the main characteristics of drought events - duration, onset, offset, severity, frequency - that require various input data. An index is a quantitative measure of drought characteristics that is computed on the basis of water storage variables. (Zargar et al., 2011).

This study aims to contribute to the area of drought monitoring by addressing the crucial part of index selection which is determined by drought type, but also data limitations.

Choosing an appropriate drought index for a specific application depends largely on the existing observations network for the geographic extent under investigation, especially in areas where data availability is an issue. In this context, the main objective of this study is to review established and recent drought indices developed for specific drought assessment and to achieve a typology, by classifying the indices based on types of data required and their purpose.

\section{DATA AND METHODS}

The methodological approach towards an index classification is a bibliographic research and analysis. Several papers have reviewed different aspects of drought monitoring and assessment and provided important reference to identify commonly used indices (Hao \& Singh, 2015; Heim, 2002; Keyantash \& Dracup, 2002; Niemeyer, 2008; Pedro-Monzonis et al., 2015; Quiring, 2009; Zargar et al., 2011).

New indices were identified by examining recent literature on the Web of Science database. The examined papers cover a timeline from 1965 up to 2018.

The indices are separated by type of application and classified according to input data within each drought assessment approach. 


\section{RESULTS AND DISCUSSIONS}

The typology of drought indices based on required parameters generally follows the classification of drought types and has been separated into several main classes: meteorological and hydrological approaches using measured or modelled data, hydro-meteorological approach using remote sensing data, agricultural approach using measured/modelled data or remote sensing data, ecological approach using remotely sensed indices and multivariate indices (Fig. 1).

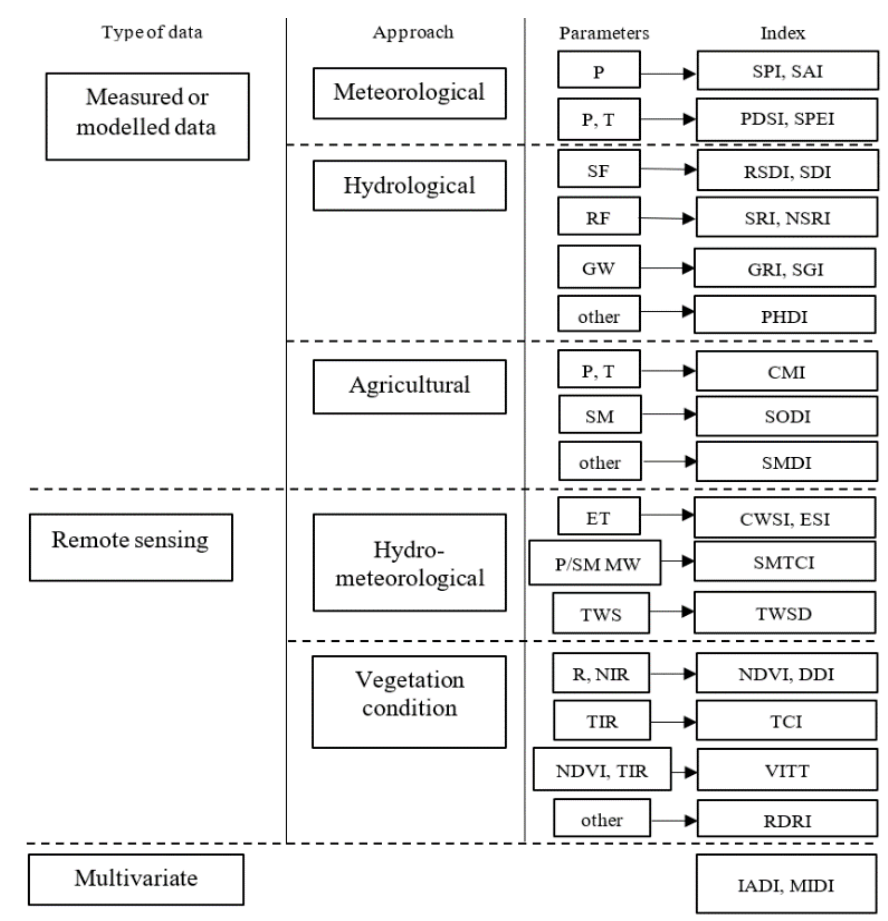

Fig. 1. Schematic representation of drought index typology. Precipitation (P), temperature (T), streamflow (SF), runoff $(\mathrm{RF})$, groundwater levels $(G W)$, soil moisture (SM), evapotranspiration (ET), microwave remote sensing (MW), total water storage gravity measurements (TWS), red (R), near infrared (NIR), thermal infrared (TIR). Indices: Standardized Precipitation Index (SPI), Standardized Anomaly Index (SAI), Palmer Drought Severity Index (PDSI), Standardized Precipitation Evapotranspiration Index (SPEI), Regional Streamflow Deficiency Index (RSDI), Streamflow Drought Index (SDI), Standardized Runoff Index (SRI), nonparametric standardized runoff index (NSRI), Groundwater Resource Index (GRI), Standardized Groundwater level Index (SGI), Palmer Hydrologic Drought Index (PHDI), Crop Moisture Index (CMI), Soil Moisture Drought Index (SODI), Soil Moisture Deficit Index (SMDI), Crop Water Stress Index (CWSI), Evaporative Stress Index (ESI), Soil Moisture and Temperature Condition Index (SMTCI), Total Water Storage Deficit (TWSD), Normalized Difference Vegetation Index (NDVI), Distance Drought Index (DDI), Temperature Condition Index (TCI), Vegetation Index / Temperature Trapezoid (VITT), Remote Sensing Drought Risk 


\section{Index (RDRI), Integrated Agricultural Drought Index (IADI), Microwave Integrated Drought Index (MIDI).}

Drought indices range from simple calculations requiring only one input parameter to multivariate indices that are calculated based on several parameters, either measured, modelled or calculated through remote sensing. A large body of literature is dedicated to the methodologies and applications of drought indices; more than 150 indices have been developed up to the year 2011 (Zargar et al., 2011). New indices are developed to better represent local geographical conditions or to apply different statistical methods.

A drought index must fulfil certain requirements to justify its usage, among which the fact that it should be relevant to the type of drought in the study, the input data should be available, consistent and of sufficient quality, it should be valid and sensitive to temporal and spatial variability (Steinemann et al., 2005). Besides data availability, the dominant climatic factors in the specific region can determine the choice between a simple or more complex index.

Determining factors for drought can follow different spatial and temporal patterns in various geographic conditions. Drought trends can be determined by decreasing rainfall, increasing temperatures, a combination of both or other limiting parameters depending on local conditions (Spinoni et al., 2015). It is therefore important to consider the regional driving forces for drought to make an index selection.

\section{Meteorological approach}

Indices using measured or modelled data for the investigation of meteorological drought mostly employ precipitation or a combination of precipitation and temperature. The most widely accepted index that only uses precipitation as input data is SPI (McKee et al., 1993), due to its simplicity. It is often used to evaluate performances of new indices. It has evolved into numerous variants such as relative SPI (rSPI) (Dubrovsky et al., 2006) or multiscalar SPI (MSPIi) (Zhu et al., 2016). Relative SPI (rSPI) was developed to overcome the problem that traditional SPI (or self-calibrated SPI) does not accurately represent different spatial patterns between sites or temporal changes because the index results in approximately the same distribution (Dubrovsky et al., 2006). A variety of other indices that only use precipitation as input data have been developed among which Standardized Anomaly Index (SAI) (Katz \& Glantz, 1986); Effective Drought Index (EDI) (Byun \& Wilhite, 1999); Drought Frequency Index (DFI) (González \& Valdés, 2006); percentage of precipitation anomaly (PPA) (Zhao et al., 2017). High temperatures increase the probability of drought by exacerbating evapotranspiration and decreasing soil moisture, therefore combining temperature measurements with precipitation is increasingly important in global warming conditions (Mukherjee et al., 2018). Indices using precipitation and temperature are the Palmer Drought Severity Index (PDSI) (Wayne, 1965), Reconnaissance Drought Index (RDI) (Tsakiris \& Vangelis, 2005), relative PDSI (rPDSI) (Dubrovsky et al., 2006), Standardized Precipitation Evapotranspiration Index (SPEI) (Vicente-Serrano et al., 2010), Standardized 
Palmer Drought Index (SPDI) (Ma et al., 2014), relative SPEI (rSPEI) (MarcosGarcia et al., 2017).

\section{Hydrological approach}

Indices developed under a hydrological approach are heavily relying on streamflow data, runoff, reservoir and groundwater levels and aim to quantify the delayed effects of drought in the hydrological system (Zargar et al., 2011), reflecting an insufficiency of water resources over a period of time. Indices using only streamflow data are: Regional Streamflow Deficiency Index (RSDI) (Stahl, 2001), Standardized Streamflow Index (SSFI) (Modarres, 2007), Streamflow Drought Index (SDI) (Nalbantis \& Tsakiris, 2009), Baseflow Index (BFI) (Gustard \& Demuth, 2009) or newer indices such as the Regional Drought Area Index (RDAI) (Fleig et al., 2011) and the relative Standardized Flow Index (rSFI) (Marcos-Garcia et al., 2017), which used the same approach as for rSPI and rSPEI. Runoff is another parameter used for assessing hydrological deficits, in indices such as nonparametric standardized runoff index (NSRI) (J. Wu et al., 2018). The Standardized Runoff Index (SRI) (Shukla \& Wood, 2008) was created analogous to the SPI, while the Water Balance Derived Drought Index (Vasiliades et al., 2011) uses a water balance model that simulates runoff data. The Surface Water Supply Index (SWSI) (Shafer \& Dezman, 1982) uses streamflow, precipitation, reservoir and snowpack data. The Palmer Hydrologic Drought Index (PHDI) (Karl, 1986) has been developed using precipitation, temperature, available water content to better display the impacts of drought on hydrological components compared to the PDSI. It responds slower to the recession of drought, reflecting the lag time between the ending of a meteorological drought and the hydrological consequences (Karl, 1986). Indices focused on groundwater levels are the Groundwater Resource Index (GRI) (Mendicino et al., 2008) and Standardized Groundwater level Index (SGI) (Bloomfield \& Marchant, 2013). In Spain, the national drought monitoring system uses a network of measuring points for streamflow, precipitation, groundwater, reservoir storage and inflow to derive the (Spanish) Status Index (SI) (PedroMonzonís et al., 2015). The standardised Status Index (iSI) was created (OrtegaGómez et al., 2018) through monthly standardization of the SI.

\section{Hydro-meteorological remote sensing approach}

Studying meteorological or hydrological droughts can be performed using remotely sensed data that captures water variability in different compartments of the hydrological system. Evapotranspiration (ET) is an essential process in drought analysis because increased ET rates can foster drought conditions similar to low rainfall (Spinoni et al., 2015) and can be neglected by the simpler indices that only account for precipitation. Some indices exploit thermal remote sensing and use ET as a parameter: Crop Water Stress Index (CWSI) (Jackson et al., 1981) or the Water Deficit Index (WDI) (Moran et al., 1994). The Evaporative Stress Index (ESI) (Anderson et al, 2011) and Evaporative Drought Index (EDI) (Yao et al., 2010) also explore the ratio between potential and actual ET, thus giving a measure of drought 
intensity. The remotely sensed Drought Severity Index (Mu et al., 2013) uses MODIS derived evapotranspiration in concurrence with NDVI, while the more recent Standardized Evapotranspiration Deficit Index (SEDI) (Kim \& Rhee, 2016; Vicente-Serrano et al., 2018) uses evapotranspiration estimates derived from remotely sensed data. Other drought indices take advantage of microwave remote sensing data, such as the Soil Water Index (SWI) (Wagner, 2003) and the Soil Moisture and Temperature Condition Index (SMTCI) (Zhang \& Jia, 2013). A series of indices were developed using satellite gravimetry owing to Gravity Recovery and Climate Experiment satellite (GRACE). GRACE measurements were used to derive maps of the Earth's gravity field which are sensitive to movements in water storage components in the hydrological system (Ramillien et al., 2008). The GRACE-based hydrological drought index (GHDI) (Yi \& Wen, 2016), Water Storage Deficit Index (WSDI) and the Total Water Storage Deficit (TWSD) (Sun et al., 2018) are drought indices based on the total water storage (TWS) changes.

\section{Agricultural approach on drought}

Agricultural drought analysis focuses on exploring water availability to crops. Decreasing soil moisture is an important limitation to crop growth. The most commonly used agricultural indices are the Palmer Moisture Anomaly Z-index ( Palmer, 1965), the Crop Moisture Index (CMI) (Palmer, 1968) both requiring precipitation and temperature data. Soil Moisture Drought Index (SODI) (Sohrabi et al., 2015) uses soil moisture as a parameter. The Evapotranspiration Deficit Index (ETDI) and the Soil Moisture Deficit Index (SMDI) use soil moisture and evapotranspiration modelled with Soil and Water Assessment Tool (SWAT) hydrologic model (Narasimhan \& Srinivasan, 2005). A new agricultural index has been recently proposed (Tigkas et al., 2018), the Agricultural Standardised Precipitation Index (aSPI) which modifies the original SPI by using effective precipitation instead of precipitation data. The authors discuss that effective precipitation better describes the availability of water to plants and therefore it is advantageous for agricultural drought identification. Hanel et al., 2018 have found that droughts related to soil moisture deficit have increasing tendencies, which is probably due to the increasing trends in temperature.

\section{Remote Sensing of Vegetation condition}

Numerous vegetation indices have been proposed for the identification of drought using remotely sensed data that focus on vegetation condition, therefore exploring the effects from an ecological perspective (AghaKouchak et al., 2015). New indices are developed along with the deployment of new sensors on satellite platforms. Among the first remote sensing drought indices were relations between the red spectral reflectance (R) and near-infrared spectral reflectance (NIR) to quantify vegetation health, the most common being the Normalized Difference Vegetation Index (NDVI) (Tucker, 1979). Chlorophyll in healthy vegetation strongly reflects in the IR and absorbs in the R band, while stressed vegetation absorbs less R, therefore representing a useful indicator of drought (Zargar et al., 2011). Other indices using 
the same bands are Perpendicular Vegetation Index (PVI) (Richardson \& Wiegand, 1977) or the Distance Drought Index (DDI) (Qin et al., 2010). Furthermore, NDVI is used as input for other indices, such as Vegetation Condition Index (VCI) (F. Kogan \& Sullivan, 1993) or the relative normalized difference vegetation index (RNDVI) (M. xin Wu \& Lu, 2016).

Rapidly developing warming events due to climate change indicate the need for early warning systems. This can direct the choice of index from a shortwave index to thermal observation, because vegetation indexes indicate drought stress after the damage determined by increasing temperature was produced (Anderson et al., 2013).

The thermal infrared observations (TIR) are used to estimate the land surface temperature (LST) to determine vegetation stress caused by high temperatures. Such indices are the Temperature Condition Index (TCI) (F. N. Kogan, 1995) built to reflect the influence of temperature on vegetation, while the Modified Temperature Condition Index (MTCI) (Sanchez et al., 2016) modified it in order to invert the scaling.

The Vegetation Health index (VT) (F. N. Kogan, 2000) combines the thermal TCI with the VCI. In addition, the relation between LST and NDVI has been explored with a wide range of indices such as the Vegetation Index /Temperature Trapezoid (VITT) (Moran et al., 1994) or the Vegetation Supply Water Index (VSWI) (Cunha et al., 2015).

The Green Vegetation Index of the Tasseled Cap (GVI) was calculated using visible and NIR bands of the Multispectral Scanner (MSS) sensor and the visible, NIR and shortwave infrared bands of the Thematic Mapper (TM) sensors on board Landsat satellites (Kauth \& Thomas, 1976). The Remote Sensing Drought Risk Index (RDRI) investigates drought by computing three cloud indexes and accounting for latitudinal and seasonal variability of the remote sensing data (Liu et al., 2008).

\section{Multivariate indices}

A series of complex multivariate indices have been created to overcome simplification of drought characterization by integrating several indices or parameters to better represent all aspects of drought. Hao \& Singh (2015) have reviewed several methods for constructing multivariate indices, among which the integration of objective and subjective indexes, the use of water balance models, statistical methods such as joint distribution or principal component analysis (PCA). The United States Drought Monitor is an ample product based on the combination of drought indices, hydrological, climatological and soil moisture parameters as well as expert knowledge (Svoboda et al., 2002). The Integrated Agricultural Drought Index (IADI) proposed by Zhao et al., 2017 uses the Evaporative Drought Index (EDI) (Yao et al., 2010) and a rarity index derived from EDI statistical structure. Taking advantage of multiple microwave remote sensing data sets to derive a Precipitation Condition Index, a Soil Moisture Condition Index and the TCI, Zhang 
\& Jia, 2013a constructed the Microwave Integrated Drought Index (MIDI) for identifying short-term droughts.

\section{CONCLUSIONS}

A brief overview of the main drought index types based on required parameters was presented in this study. Quantifying the characteristics of dry spells over a region is essential for water resource management, and this can be performed using either in-situ or remotely sensed data. However, availability of long-term precipitation or streamflow records might be a challenging issue in many regions of the world. In this case remote sensing drought observations have increasing importance.

At the same time, it is increasingly important for new or revised indices to take into consideration the projected trends in surface warming over the $21^{\text {st }}$ century (Dai, 2011). The synthesis of index types may determine the selection of appropriate methodologies for drought assessment, because it provides a decision instrument based on data availability, type and complexity of drought under study.

\section{REFERENCES}

1. AghaKouchak, A., Farahmand, A., Melton, F. S., Teixeira, J., Anderson, M. C., Wardlow, B. D., \& Hain, C. R. (2015). Remote sensing of drought: Progress, challenges and opportunities. Reviews of Geophysics, 53(2), 452-480.

2. Allen, C. D., Macalady, A. K., Chenchouni, H., Bachelet, D., McDowell, N., Vennetier, M., ... Cobb, N. (2010). A global overview of drought and heat-induced tree mortality reveals emerging climate change risks for forests. Forest Ecology and Management, 259(4, SI), 660-684. https://doi.org/10.1016/j.foreco.2009.09.001

3. Anderson, M. C., Hain, C., Otkin, J., Zhan, X., Mo, K., Svoboda, M., ... Pimstein, A. (2013). An Intercomparison of Drought Indicators Based on Thermal Remote Sensing and NLDAS-2 Simulations with U.S. Drought Monitor Classifications. Journal of Hydrometeorology, 14(4), 1035-1056. https://doi.org/10.1175/JHM-D-12-0140.1

4. Bachmair, S., Stahl, K., Collins, K., Hannaford, J., Acreman, M., Svoboda, M., ... Overton, I. C. (2016). Drought indicators revisited: the need for a wider consideration of environment and society. Wiley Interdisciplinary Reviews - Water, 3(4), 516-536. https://doi.org/10.1002/wat2.1154

5. Bloomfield, J. P., \& Marchant, B. P. (2013). Analysis of groundwater drought building on the standardised precipitation index approach. Hydrology and Earth System Sciences, 17(12), 4769-4787. https://doi.org/10.5194/hess-17-4769-2013

6. Byun, H. R., \& Wilhite, D. A. (1999). Objective quantification of drought severity and duration. Journal of Climate, 12(9), 2747-2756. https://doi.org/10.1175/15200442(1999)012<2747:OQODSA>2.0.CO;2

7. Ciais, P., Reichstein, M., Viovy, N., Granier, A., Ogée, J., Allard, V., ... Valentini, R. (2005). Europe-wide reduction in primary productivity caused by the heat and drought in 2003. Nature, 437(7058), 529-533. https://doi.org/10.1038/nature03972

8. Cunha, A. P. M., Alvala, R. C., Nobre, C. A., \& Carvalho, M. A. (2015). Monitoring vegetative drought dynamics in the Brazilian semiarid region. Agricultural and Forest Meteorology, 214, 494-505. https://doi.org/10.1016/j.agrformet.2015.09.010 
9. Dubrovsky, M., Svoboda, M. D., Trnka, M., Hayes, M. J., Wilhite, D. A., Zalud, Z., \& Hlavinka, P. (2006). Application of Relative Drought Indices in Assessing ClimateChange Impacts on Drought Conditions in Czechia. Theoretical and Applied Climatology 96, 96.

10. Fleig, A. K., Tallaksen, L. M., Hisdal, H., \& Hannah, D. M. (2011). Regional hydrological drought in north-western Europe: Linking a new Regional Drought Area Index with weather types. Hydrological Processes, 25(7), 1163-1179. https://doi.org/10.1002/hyp.7644

11. González, J., \& Valdés, J. B. (2006). New drought frequency index: Definition and comparative performance analysis. Water Resources Research, 42(11), 1-13. https://doi.org/10.1029/2005WR004308

12. Hanel, M., Rakovec, O., Markonis, Y., Máca, P., Samaniego, L., Kyselý, J., \& Kumar, R. (2018). Revisiting the recent European droughts from a long-term perspective. Scientific Reports, 8(1), 1-11. https://doi.org/10.1038/s41598-018-27464-4

13. Hao, Z., \& Singh, V. P. (2015). Drought characterization from a multivariate perspective: A review. Journal of Hydrology, 527, 668-678.

14. Heim, R. R. (2002). A review of twentieth-century drought indices used in the United States. Bulletin of the American Meteorological Society, 83(8), 1149-1165.

15. Hoegh-Guldberg, O., Jacob, D., Taylor, M., Bindi, M., Brown, S., Camilloni, I., ... Zhou, G. (2018). Impacts of $1.5^{\circ} \mathrm{C}$ of Global Warming on Natural and Human Systems. In Global warming of $1.5^{\circ} \mathrm{C}$. An IPCC Special Report on the impacts of global warming of $1.5^{\circ} \mathrm{C}$ above pre-industrial levels and related global greenhouse gas emission pathways, in the context of strengthening the global response to the threat of climate change,.

16. Jackson, R. D., Idso, S. B., Reginato, R. J., \& Pinter, P. J. (1981). Canopy Temperature as a Crop Water Stress Indicator, 17(4), 1133-1138.

17. Kallis, G. (2008). Droughts. Annual Review of Environment and Resources, 33, 85118. https://doi.org/10.1146/annurev.environ.33.081307.123117

18. Karl, T. R. (1986). The sensitivity of the palmer drought severity index and palmer zindex to their calibration coefficients including potential evapotranspiration. Journal of Climate and Applied Meteorology, 25(1), 77-86. https://doi.org/10.1175/15200450(1986)025<0077:TSOTPD>2.0.CO;2

19. Katz, R. W., \& Glantz, M. H. (1986). Anatomy of a Rainfall Index. Monthly Weather Review. https://doi.org/10.1175/1520-0493(1986)114<0764:AOARI>2.0.CO;2

20. Kauth, R. J., \& Thomas, G. S. (1976). The tasselled cap - A graphic description of the spectral-temporal development of agricultural crops as seen by Landsat. Laboratory for Applications of Remote Sensing, 41-51. https://doi.org/10.1529/biophysj.106.083931

21. Keyantash, J., \& Dracup, J. A. (2002). The quantification of drought: An evaluation of drought indices. Bulletin of the American Meteorological Society, 83(8), $1167-$ 1180.

22. Kim, D., \& Rhee, J. (2016). A drought index based on actual evapotranspiration from the Bouchet hypothesis. https://doi.org/10.1002/2016GL070302

23. Kogan, F. N. (1995). Application of vegetation index and brightness temperature for drought detection. Advances in Space Research, 15(11), 91-100. https://doi.org/10.1016/0273-1177(95)00079-T

24. Kogan, F. N. (2000). Contribution of Remote Sensing to Drought Early Warning. In Early Warning Systems for Drought Preparedness and Drought Management.

25. Kogan, F., \& Sullivan, J. (1993). Drought-Watch System Using Noaa / Avhrr Data. 
America, 13(5), 219-222.

26. Liu, L., Xiang, D., Zhou, Z., \& Dong, X. (2008). Analyses the modification functions of the drought monitoring model based on the cloud parameters method. Proceedings - 1st International Congress on Image and Signal Processing, CISP 2008, 4, 687-691. https://doi.org/10.1109/CISP.2008.431

27. Ma, M., Ren, L., Singh, V. P., Yang, X., Yuan, F., \& Jiang, S. (2014). New variants of the Palmer drought scheme capable of integrated utility. Journal of Hydrology, 519, 1108-1119. https://doi.org/10.1016/J.JHYDROL.2014.08.041

28. Marcos-Garcia, P., Lopez-Nicolas, A., \& Pulido-Velazquez, M. (2017). Combined use of relative drought indices to analyze climate change impact on meteorological and hydrological droughts in a Mediterranean basin. Journal of Hydrology, 554, 292-305. https://doi.org/10.1016/j.jhydrol.2017.09.028

29. McKee, T. B., Doesken, N. J., Kleist, J. (1993, January). The relationship of drought frequency and duration to time scales. Proceedings of the 8th Conference on Applied Climatology, 179-184. https://doi.org/citeulike-article-id:10490403

30. Mendicino, G., Senatore, A., \& Versace, P. (2008). A Groundwater Resource Index (GRI) for drought monitoring and forecasting in a mediterranean climate. Journal of Hydrology, 357(3-4), 282-302. https://doi.org/10.1016/j.jhydrol.2008.05.005

31. Mishra, A. K., \& Singh, V. P. (2010). A review of drought concepts. Journal of Hydrology, 391(1-2), 204-216. https://doi.org/10.1016/j.jhydrol.2010.07.012

32. Modarres, R. (2007). Streamflow drought time series forecasting. Stochastic Environmental Research and Risk Assessment, 21(3), 223-233. https://doi.org/10.1007/s00477-006-0058-1

33. Moran, M. S., Clarke, T. R., Inoue, Y., \& Vidal, A. (1994). Estimating Crop Water Deficit Using the Relation between Surface-Air Temperature and Spectral Vegetation Index, 263(April 1994), 246-263.

34. Mu, Q., Zhao, M., Kimball, J. S., McDowell, N. G., \& Running, S. W. (2013). A remotely sensed global terrestrial drought severity index. Bulletin of the American Meteorological Society, 94(1), 83-98. https://doi.org/10.1175/BAMS-D-11-00213.1

35. Mukherjee, S., Mishra, A., \& Trenberth, K. E. (2018). Climate Change and Drought: a Perspective on Drought Indices. Current Climate Change Reports, 4(2), 145-163. https://doi.org/10.1007/s40641-018-0098-x

36. Nalbantis, I., \& Tsakiris, G. (2009). Assessment of Hydrological Drought Revisited. Water Resources Management, 23(5), 881-897. https://doi.org/10.1007/s11269-0089305-1

37. Narasimhan, B., \& Srinivasan, R. (2005). Development and evaluation of Soil Moisture Deficit Index (SMDI) and Evapotranspiration Deficit Index (ETDI) for agricultural drought monitoring. Agricultural and Forest Meteorology, 133(1-4), 6988. https://doi.org/10.1016/j.agrformet.2005.07.012

38. Niemeyer, S. (2008). New drought indices. Drought Managment: Scientific and $\begin{array}{lll}\text { Technological } & \text { Innovations, } & \text { 267-274 }\end{array}$ https://doi.org/10.1017/CBO9781107415324.004

39. Ortega-Gómez, T., Pérez-Martín, M. A., \& Estrela, T. (2018). Improvement of the drought indicators system in the Júcar River Basin, Spain. Science of the Total Environment, 610-611, 276-290. https://doi.org/10.1016/j.scitotenv.2017.07.250

40. Palmer, W. C. (1965). Meteorological Drought. U.S. Departmente of Commerce, 45(45), 58. https://doi.org/10.1111/j.1467-9523.2006.00307.x

41. Palmer, W. C. (1968). Keeping track of crop moisture conditions, nationwide: The new crop moisture index. Weatherwise, 21(4), 156-61. 
42. Pedro-Monzonís, M., Solera, A., Ferrer, J., Estrela, T., \& Paredes-Arquiola, J. (2015). A review of water scarcity and drought indexes in water resources planning and management. Journal of Hydrology, 527, 482-493. https://doi.org/10.1016/j.jhydrol.2015.05.003

43. Qin, Q., Jin, C., Zhang, N., \& Yang, X. (2010). An two-dimensional spectral space based model for drought monitoring and its re-examination. International Geoscience and Remote Sensing Symposium (IGARSS), 3869-3872. https://doi.org/10.1109/IGARSS.2010.5649710

44. Quiring, S. M. (2009). Monitoring drought: An evaluation of meteorological drought indices. Geography Compass, 3(1), 64-88. https://doi.org/10.1111/j.17498198.2008.00207.x

45. Ramillien, G., Famiglietti, J. S., \& Wahr, J. (2008). Detection of continental hydrology and glaciology Signals from GRACE: A review. Surveys in Geophysics, 29(4-5), 361-374. https://doi.org/10.1007/s10712-008-9048-9

46. Richardson, A. J., \& Wiegand, C. L. (1977). Distinguishing vegetation from soil background information. Photogrammetric Engineering and Remote Sensing. Photogrammetric Engineering and Remote Sensing, 43(12), 1541-1552.

47. Sanchez, N., Gonzalez-Zamora, A., Piles, M., \& Martinez-Fernandez, J. (2016). A New Soil Moisture Agricultural Drought Index (SMADI) Integrating MODIS and SMOS Products: A Case of Study over the Iberian Peninsula. Remote Sensing, 8(4). https://doi.org/10.3390/rs8040287

48. Shafer, B. A., \& Dezman, L. E. (1982). Development of a surface water supply index (SWSI) to assess the severity of drought conditions in snowpack runoff areas. Western Snow Conference. https://doi.org/10.1016/j.fcr.2011.05.019

49. Shukla, S., \& Wood, A. W. (2008). Use of a standardized runoff index for characterizing hydrologic drought. Geophysical Research Letters, 35(2), 1-7. https://doi.org/10.1029/2007GL032487

50. Smakhtin, V. U. (2001). Low flow hydrology: a review. Journal of Hydrology, 240(34), 147-186. https://doi.org/10.1016/S0022-1694(00)00340-1

51. Sohrabi, M. M., Ryu, J. H., Abatzoglou, J., \& Tracy, J. (2015). Development of Soil Moisture Drought Index to Characterize Droughts. Journal of Hydrologic Engineering, 20(11), 04015025. https://doi.org/10.1061/(ASCE)HE.19435584.0001213

52. Spinoni, J., Naumann, G., Vogt, J., \& Barbosa, P. (2015). European drought climatologies and trends based on a multi-indicator approach. Global and Planetary Change, 127, 50-57. https://doi.org/10.1016/j.gloplacha.2015.01.012

53. Spinoni, J., Vogt, J. V., Naumann, G., Barbosa, P., \& Dosio, A. (2018). Will drought events become more frequent and severe in Europe? International Journal of Climatology, 38(4), 1718-1736. https://doi.org/10.1002/joc.5291

54. Stahl, K. (2001). Hydrological Drought - a Study across Europe (PhD Thesis). Freiburger Schriften Zur Hydrologie, 15, 1-129.

55. Steinemann, A.C., Hayes, M.J., and Cavalcanti, L. (2005). Drought indicators and triggers. Drought and water crises. Science,technology, and management issues.

56. Sun, Z., Zhu, X., Pan, Y., Zhang, J., \& Liu, X. (2018). Drought evaluation using the GRACE terrestrial water storage deficit over the Yangtze River Basin, China. Science of the Total Environment, 634, 727-738. https://doi.org/10.1016/j.scitotenv.2018.03.292

57. Svoboda, M., LeComte, D., Hayes, M., Heim, R., Gleason, K., Angel, J., ... Stephens, S. (2002). The drought monitor. Bulletin of the American Meteorological Society, 
83(8), 1181-1190.

58. Tigkas, D., Vangelis, H., \& Tsakiris, G. (2018). Drought characterisation based on an agriculture-oriented standardised precipitation index. Theoretical and Applied Climatology, 1-13. https://doi.org/10.1007/s00704-018-2451-3

59. Tsakiris, G., \& Vangelis, H. (2005). Establishing a Drought Index Incorporating Evapotranspiration. European Water, 9(10), 3-11.

60. Tucker, C. J. (1979). Red and Photographic Infrared Linear Combinations for Monitoring Vegetation. Remote Sensing of Environment, 8(2), 127-150.

61. Van Vliet, M. T. H., Sheffield, J., Wiberg, D., \& Wood, E. F. (2016). Impacts of recent drought and warm years on water resources and electricity supply worldwide. Environmental Research Letters, 11(12). https://doi.org/10.1088/17489326/11/12/124021

62. Vasiliades, L., Loukas, A., \& Liberis, N. (2011). A Water Balance Derived Drought Index for Pinios River Basin, Greece. Water Resources Management, 25(4), 10871101. https://doi.org/10.1007/s11269-010-9665-1

63. Vicente-Serrano, S. M., Begueria, S., \& Lopez-Moreno, J. I. (2010). A Multiscalar Drought Index Sensitive to Global Warming: The Standardized Precipitation Evapotranspiration Index. Journal of Climate, 23(7), 1696-1718. https://doi.org/10.1175/2009JCLI2909.1

64. Vicente-Serrano, S. M., Miralles, D. G., Domínguez-Castro, F., Azorin-Molina, C., El Kenawy, A., Mcvicar, T. R., ... Peña-Gallardo, M. (2018). Global assessment of the standardized evapotranspiration deficit index (SEDI) for drought analysis and monitoring. Journal of Climate, 31(14), 5371-5393. https://doi.org/10.1175/JCLI-D$17-0775.1$

65. Wagner, W. (2003). Evaluation of the agreement between the first global remotely sensed soil moisture data with model and precipitation data. Journal of Geophysical Research, 108(D19), 4611. https://doi.org/10.1029/2003JD003663

66. Wilhite, D. A. (2000). Chapter 1 Drought as a Natural Hazard. Drought Mitigation Center Faculty Publications, 69.

67. Gustard, A. \& Demuth, S. (2009). Manual on low-flow estimation and prediction. Operational Report No 50, WMO-No. 1029, 136p.

68. Wu, J., Miao, C., Tang, X., Duan, Q., \& He, X. (2018). A nonparametric standardized runoff index for characterizing hydrological drought on the Loess Plateau, China. Global and Planetary Change, 161(June 2017), 53-65. https://doi.org/10.1016/j.gloplacha.2017.12.006

69. Wu, M. xin, \& Lu, H. quan. (2016). A modified vegetation water supply index (MVWSI) and its application in drought monitoring over Sichuan and Chongqing, China. Journal of Integrative Agriculture, 15(9), 2132-2141. https://doi.org/10.1016/S2095-3119(15)61257-6

70. Yao, Y., Liang, S., Qin, Q., \& Wang, K. (2010). Monitoring Drought over the Conterminous United States Using MODIS and NCEP Reanalysis-2 Data, 16651680. https://doi.org/10.1175/2010JAMC2328.1

71. Yi, H., \& Wen, L. (2016). Satellite gravity measurement monitoring terrestrial water storage change and drought in the continental United States. Nature Publishing Group, (December 2015), 1-9. https://doi.org/10.1038/srep19909

72. Zargar, A., Sadiq, R., Naser, B., \& Khan, F. I. (2011). A review of drought indices. Environmental Reviews, 19, 333-349. https://doi.org/10.1139/A11-013

73. Zhang, A., \& Jia, G. (2013). Monitoring meteorological drought in semiarid regions using multi-sensor microwave remote sensing data. Remote Sensing of Environment, 
134, 12-23. https://doi.org/10.1016/j.rse.2013.02.023

74.Zhao, H., Xu, Z., Zhao, J., \& Huang, W. (2017). A drought rarity and evapotranspiration-based index as a suitable agricultural drought indicator. Ecological Indicators, 82(June), 530-538. https://doi.org/10.1016/j.ecolind.2017.07.024

75. Zhu, Y., Wang, W., Singh, V. P., \& Liu, Y. (2016). Combined use of meteorological drought indices at multi-time scales for improving hydrological drought detection. Science of the Total Environment, 571(1), 1058-1068. https://doi.org/10.1016/j.scitotenv.2016.07.096 
